\title{
Sulfur dioxide emissions during the 2011 eruption of Shinmoedake volcano, Japan
}

\author{
Toshiya Mori $^{1}$ and Koji Kato ${ }^{2 *}$ \\ ${ }^{1}$ Geochemical Research Center, Graduate School of Science, The Univ. of Tokyo, 7-3-1 Hongo, Bunkyo-ku, Tokyo 113-0033, Japan \\ ${ }^{2}$ Fukuoka District Meteorological Observatory, Japan Meteorological Agency, 1-2-36 Ohori, Chuo-ku, Fukuoka 810-0052, Japan
}

(Received November 4, 2012; Revised April 18, 2013; Accepted April 19, 2013; Online published July 8, 2013)

\begin{abstract}
Sulfur dioxide flux of the 2011 Shinmoedake eruption, which started in January 2011, was measured repeatedly throughout its activity. The $\mathrm{SO}_{2}$ flux, which was greater than 10,000 ton/day during the earlier stages, quickly decreased to below 1,000 ton/day over the following two weeks. The flux decreased gradually thereafter to about 200 ton/day by the second half of March 2011. It continued at that level until April 2012. To evaluate the amount of $\mathrm{SO}_{2}$ emitted during the 2011 eruption, daily $\mathrm{SO}_{2}$ flux was estimated based on direct observations and other information. The total $\mathrm{SO}_{2}$ emissions were about $280 \mathrm{kt}$, with nearly two-thirds emitted during the first two weeks. The degrees of excess degassing estimated for the lava accumulation stages were low (2.3-2.9), suggesting a small pre-eruptive bubble content in the magma. High $\mathrm{SO}_{2}$ flux observed immediately after the sub-Plinian eruptions and before rapid lava effusion is probably related to the extensive degassing of magma in the conduit, which probably played a role in the transition from explosive to effusive eruption. An abrupt and large flux decrease occurred around February 8, 2011, which might be attributable to depletion of pre-eruptive bubbles in the magma.
\end{abstract}

Key words: The Shinmoedake 2011 eruption, volcanic gas flux, $\mathrm{SO}_{2}$ flux, DOAS.

\section{Introduction}

Volcanic gas flux, which reflects the amount, depth, and volatile content of magma beneath a volcanic system, is an important monitoring tool that is useful to elucidate changes in volcanic activity. The volcanic gas flux is usually reported by the flux of $\mathrm{SO}_{2}$, a major component, because it easier to detect by remote sensing than other volcanic gas species are. Regarding the Pinatubo eruption in 1992, $\mathrm{SO}_{2}$ flux variation observed before the climatic eruption was a key to raising the alert level of the volcano and for earlier evacuation of local residents (Daag et al., 1996). For nearly 30 years since the beginning of the 1970s, a correlation spectrometer (COSPEC, e.g., Stoiber et al., 1983) has been almost the only ground based instrument used to measure the $\mathrm{SO}_{2}$ flux at volcanoes. In the early 2000s, a handheld UV spectrometer was introduced for volcanic $\mathrm{SO}_{2}$ flux measurements (Galle et al., 2002), bringing considerable improvement in volcanic gas flux monitoring because of its size, low price, and portability. At present, hand-held spectrometer-based systems have completely replaced the COSPEC. They are used at many volcanoes around the world (i.e., McGonigle et al., 2004; Oppenheimer et al., 2004; Mori et al., 2006a; Bani et al., 2012).

*Now at: Seismological and Volcanological Department, Japan Meteorological Agency, 1-3-4 Otemachi, Chiyoda-ku, Tokyo 100-8122, Japan.

Copyright (C) The Society of Geomagnetism and Earth, Planetary and Space Sciences (SGEPSS); The Seismological Society of Japan; The Volcanological Society of Japan; The Geodetic Society of Japan; The Japanese Society for Planetary Sciences; TERRAPUB.

doi:10.5047/eps.2013.04.005
Ground observations and satellite based instrument measurements of many explosive and effusive volcanic eruptions compiled by Shinohara (2008) show that $\mathrm{SO}_{2}$ emissions are usually greater than those estimated using erupted magma mass and dissolved $\mathrm{S}$ content in magma obtained in petrological studies. This difference is called "excess degassing". Because understanding of the degree of excess degassing and its mechanisms can provide insight into eruption processes (Shinohara, 2008), it is important to obtain both directly measured and petrologically estimated amounts of $\mathrm{SO}_{2}$ emissions accurately. For gas emission measurements, it is necessary to measure the variation of the flux throughout the eruptive activity, including the post eruptive degassing period.

This paper reports $\mathrm{SO}_{2}$ flux variation observed throughout the 2011 eruption of Shinmoedake volcano, Kirishima volcano complex, Japan. We started $\mathrm{SO}_{2}$ flux measurements using a compact UV-spectrometer-based system from the day after the beginning of magmatic eruptive activity on January 26, 2011. The objective of this report is to clarify relations between the $\mathrm{SO}_{2}$ flux and surface eruptive activity during the 2011 eruption.

\section{Shinmoedake Volcano}

The Kirishima volcano complex, which is located in the southern part of Kyushu Island, Japan, consists of multiple volcanic centers. Shinmoedake volcano, one of its craters, rises to an altitude of $1421 \mathrm{~m}$ a.s.l. During the last 60 years, phreatic eruptions have taken place in 1959 , 1991, 2008, with seven others occurring in March-July, 2010 (JMA, 2005, 2011; Geshi et al., 2010). The 2011 
Shinmoedake eruption that began in January 2011 was its first magmatic eruption in about 300 years. On January 19, 2011, a phreatic eruption occurred a week before the onset of the magmatic eruption. A sub-Plinian eruption started on the afternoon of January 26. Three stages of sub-Plinian eruption occurred up through January 27 (Nakada et al., 2013). A small, approximately 50-m-diameter lava dome was observed at the bottom of the summit crater by aircraft monitoring on the morning of January 28 (Nakada et al., 2013). Lava filled the crater in 4 days, reaching a volume of about $1.5 \times 10^{7} \mathrm{~m}^{3}$ (GIAJ, 2012). From the beginning of February, the volcano had intermittent vulcanian eruptions through September 2011 (JMA, 2012; Nakada et al., 2013). The eruptions were frequent during the first week of February, but their frequency decreased gradually over the next seven months (JMA, 2012). Continuous degassing activity was observed throughout the 2011 Shinmoedake eruption until at least June 2012.

Shinmoedake volcano was not regarded as an important $\mathrm{SO}_{2}$ degassing volcano until its 2011 eruption. Sulfur dioxide fluxes measured in 1977 and 1982 were less than 5 ton/day and much less than 10 ton/day, respectively, implying that the volcano was not a $\mathrm{SO}_{2}$ emitter (Kamada et al., 1986). $\mathrm{A} \mathrm{SO}_{2}$ flux of several tens of ton/day was observed at the volcano 10 days after the phreatic eruption of August 22, 2008 (Geshi et al., 2010). After the eruption in 2008, intermittent small plume emissions were the typical activity before the phreatic eruption of January 19, 2011, before which we presume that $\mathrm{SO}_{2}$ flux had been negligible.

\section{3. $\mathrm{SO}_{2}$ Flux Measurements}

Sulfur dioxide flux measurements were conducted using a compact UV spectrometer system (COMPUSS; Mori et al., 2007), which is a Japanese version of MiniDOAS (Galle et al., 2002) or Flyspec (Horton et al., 2006). USB2000 or USB2000+ spectrometers (Ocean Optics Inc.) were used for COMPUSS, which is calibrated with $\mathrm{SO}_{2}$ sealed quartz cells. Its output was checked before and after measurements using these cells. The spectral analysis method is based on differential optical absorption spectroscopy (DOAS; Galle et al., 2002; Platt and Stutz, 2008), which is explained in an earlier report by Mori et al. (2007).

Measurements were conducted using the traverse method with a car (Fig. 1). On January 27 during the sub-Plinian eruptions, measurements were conducted over $30 \mathrm{~km}$ distant from the volcano because the great amount of ash in the plume prevented transmission of UV light. The traverse route came closer to the volcano as the amount of ash decreased in the plume with time (Fig. 1). In the case of a south wind, when the plume is flowing northward, the volcanic plume of Sakurajima volcano (about $50 \mathrm{~km}$ south), which has a $\mathrm{SO}_{2}$ flux of more than 1,000 ton/day, interfered with the measurements. Therefore, quantification of Shinmoedake's $\mathrm{SO}_{2}$ flux was not possible in such conditions especially after the flux of Shinmoedake decreased below several hundred tons per day. Plume speed is necessary to conduct flux calculations. We used live video camera images to ascertain the plume height and used the wind speed at a corresponding plume height above Shinmoedake volcano using grid point value (GPV) data obtained from numeri- cal weather prediction by the Japan Meteorological Agency. The $\mathrm{SO}_{2}$ flux measurements were conducted by personnel from the Japan Meteorological Agency and from The University of Tokyo.

\section{Results}

Continuous plume emissions were observed on January 22 and 25 with a near-infrared video camera set at about 50 $\mathrm{km} \mathrm{SSW}$ of the volcano (Kinoshita et al., 2011). We examined images of a live video camera set at about $7.5 \mathrm{~km}$ SWS of the volcano by the Japan Meteorological Agency between January 19 and 26, which revealed that the continuous plume emissions started in the afternoon on January 21 and lasted until the onset of the magmatic eruption on January 26. The continuous plume emission was followed by magmatic eruption. Therefore, intense $\mathrm{SO}_{2}$ emission probably started on Jan. 21. However, the $\mathrm{SO}_{2}$ flux before the 2011 eruption is not known. To relate the observed $\mathrm{SO}_{2}$ flux and surface activities, the 2011 Shinmoedake eruption after January 26 was subdivided into the following three stages: sub-Plinian eruption (January 26-27, 2011), lava accumulation (January 28-31, 2011), and continuous degassing and intermittent vulcanian eruption, hereinafter the CV stage (February 1, 2011-March 31, 2012). The first week of the third stage had more frequent vulcanian eruptions. Therefore, we designate this period (February 1-7, 2011) as the earlier CV stage.

The observed $\mathrm{SO}_{2}$ flux ranged from more than 10,000 ton/day to less than 100 ton/day during the 2011 Shinmoedake eruption (Table 1 and Fig. 2). On January 27, 2011, during the sub-Plinian eruption stage, the traverses were conducted about $30 \mathrm{~km}$ southeast from the volcano (Fig. 1). The highest flux value of 42,600 ton/day was observed on January 28, corresponding to the early part of the lava accumulation stage. The flux decreased to about 10,000 ton/day in the latter half of the lava accumulation stage (Table 1). The flux continued to decrease but remained more than 5,000 ton/day at the beginning of the CV stage. During February 4-20, we were unable to take measurements. When we resumed measurements, the flux had significantly decreased to below 1,000 ton/day (Fig. 2). The flux continued its gradual decrease to a few hundred ton/day by the second half of March, continuing at that level through April 2012 except for short periods after some of eruptions during which the flux increased to over 1,000 ton/day (Fig. 2). After April 2012, the flux remained either a few tens of tons per day or was not detected, with the exception of one measurement in June 2012. We assume that $\mathrm{SO}_{2}$ degassing related to the 2011 eruption finished by the end of March 2012.

To evaluate the total amount of $\mathrm{SO}_{2}$ emitted during the 2011 eruption, we must estimate $\mathrm{SO}_{2}$ flux values for days without $\mathrm{SO}_{2}$ observations. The $\mathrm{SO}_{2}$ flux for continuous plume degassing before the onset of the magmatic eruption is completely unknown. Thereby our evaluation starts from the day that the eruption began. For the estimations of daily $\mathrm{SO}_{2}$ flux (solid lines in Fig. 2), we used the interpolation of observed $\mathrm{SO}_{2}$ flux data (Table 1) together with the following information: images of two live video cameras set about $3 \mathrm{~km}$ NWW by Kagoshima Prefecture and $7.5 \mathrm{~km}$ 
Table 1. Sulfur dioxide flux observed during the 2011 Shinmoedake eruption.

\begin{tabular}{|c|c|c|c|c|c|c|}
\hline Date & No. of traverses & $\begin{array}{l}\text { Av. flux } \\
\text { (ton/day) }\end{array}$ & $\begin{array}{l}\text { Max flux } \\
\text { (ton/day) }\end{array}$ & $\begin{array}{l}\text { Min flux } \\
\text { (ton/day) }\end{array}$ & $\begin{array}{l}\text { Wind speed } \\
(\mathrm{m} / \mathrm{s})\end{array}$ & Institution* \\
\hline 27-Jan-11 & 10 & 15,000 & 22,200 & 9,800 & 19 & JMA\&UT \\
\hline 28-Jan-11 & 3 & 42,600 & 56,300 & 24,500 & 19 & UT \\
\hline 30-Jan-11 & 3 & 11,000 & 11,000 & 11,000 & 20 & JMA \\
\hline 01-Feb-11 & 5 & 8,800 & 12,200 & 6,600 & $3-7$ & UT \\
\hline 02-Feb-11 & 5 & 5,500 & 7,000 & 4,600 & $7-11$ & UT \\
\hline 03-Feb-11 & 13 & 8,400 & 15,200 & 2,200 & $12-14$ & UT \\
\hline 21-Feb-11 & 2 & 150 & 180 & 100 & 2 & UT \\
\hline 25-Feb-11 & 16 & 770 & 2,900 & 130 & 8 & JMA \\
\hline 02-Mar-11 & 6 & 1,300 & 1,600 & 1,000 & 11 & JMA \\
\hline 08-Mar-11 & 13 & 330 & 430 & 270 & $8-15$ & JMA\&UT \\
\hline 09-Mar-11 & 12 & 320 & 440 & 220 & $13-15$ & UT \\
\hline 10-Mar-11 & 8 & 640 & 1,100 & 400 & $9-10$ & JMA\&UT \\
\hline 15-Mar-11 & 22 & 480 & 990 & 320 & $6-12$ & JMA\&UT \\
\hline 16-Mar-11 & 8 & 270 & 360 & 230 & $13-15$ & UT \\
\hline 17-Mar-11 & 22 & 230 & 520 & 160 & $7-12$ & JMA\&UT \\
\hline 30-Mar-11 & 3 & 200 & 300 & 200 & 5 & JMA \\
\hline 02-Apr-11 & 5 & 200 & 200 & 200 & $5-8$ & JMA \\
\hline 13-Мay-11 & 5 & 200 & 200 & 100 & $15-16$ & JMA \\
\hline 18-May-11 & 6 & 200 & 290 & 160 & $3-4$ & UT \\
\hline 09-Jun-11 & 5 & 400 & 530 & 200 & $4-6$ & JMA \\
\hline 24-Jun-11 & 6 & 1,400 & 1,820 & 970 & $8.6-11.7$ & JMA \\
\hline 03-Aug-11 & 22 & 100 & 180 & 50 & $13-15.5$ & JMA\&UT \\
\hline 29-Aug-11 & 6 & 130 & 220 & 100 & $5.4-8.0$ & JMA \\
\hline 01-Sep-11 & 6 & 2,000 & 2,600 & 1,630 & $12.7-13.0$ & JMA \\
\hline 02-Sep-11 & 6 & 2,200 & 2,500 & 1,970 & 18.8 & JMA \\
\hline 07-Sep-11 & 4 & 210 & 350 & 50 & $2.3-3.4$ & JMA \\
\hline 01-Nov-11 & 6 & 260 & 440 & 190 & 8.3 & JMA \\
\hline 21-Nov-11 & 4 & 340 & 450 & 170 & $7.3-8.5$ & JMA \\
\hline 20-Dec-11 & 4 & 220 & 260 & 160 & 6.2 & JMA \\
\hline 10-Jan-12 & 5 & 470 & 660 & 340 & $9.9-11.9$ & JMA \\
\hline 23-Jan-12 & 5 & 220 & 310 & 90 & $5.1-13.4$ & JMA \\
\hline 03-Feb-12 & 4 & 320 & 370 & 240 & $8.1-10.3$ & UT \\
\hline 17-Feb-12 & 6 & 210 & 310 & 190 & $13.4-15.7$ & JMA \\
\hline 19-Feb-12 & 4 & 330 & 440 & 250 & $7.9-8.6$ & UT \\
\hline 13-Mar-12 & 4 & 40 & 60 & 20 & $2.7-3.6$ & UT \\
\hline 22-Mar-12 & 5 & 120 & 170 & 60 & 7.9 & JMA \\
\hline 06-Apr-12 & 4 & 130 & 150 & 100 & 9.8 & JMA \\
\hline
\end{tabular}

*Institution conducting the measurements. (JMA: Japan Meteorological Agency; UT: The University of Tokyo)

SWS of the volcano by the Japan Meteorological Agency, maximum plume height variations (JMA, 2012) and Ozone Mapping Instrument (OMI) images of $\mathrm{SO}_{2}$ (e.g., Krotkov et al., 2006) from the global sulfur dioxide monitoring web page of NASA (http://so2.gsfc.nasa.gov/). The information above was especially useful for February 4-20, 2011, during which time significant flux decrease occurred, although no direct flux measurements were made.

The flux observed on January 27 was 10,000-22,000, with an average of 15,000 ton/day (Table 1). Because substantial eruptive activity started in the afternoon on January 26 , we evaluated the flux on that day as half of the flux on January 27 . We presume that the estimated $\mathrm{SO}_{2}$ flux for the sub-Plinian eruption stage is considerably underestimated because our measurements were not conducted during peak sub-Plinian events (see the last paragraph of Section 5 for details.).

During the lava accumulation stage, 42,600 and 11,000 ton/day were observed respectively on January 28 and 30 . For flux variation during the lava accumulation stage, OMI data were used to support the estimation. A large $\mathrm{SO}_{2}$ plume related to Shinmoedake volcano was visible on OMI images of January 28 and 29. In contrast, the $\mathrm{SO}_{2}$ plumes in the OMI images on January 30 and 31 were weak. Therefore, we inferred that the fluxes on January 29 and 31 were the same as those observed on Jan. 28 and 30, respectively, and estimated the flux of January 28 and 29 as 40,000 ton/day and of January 30 and 31 as 11,000 ton/day (Fig. 2(b)).

The $\mathrm{SO}_{2}$ flux decreased an order of magnitude in the first three weeks of the CV stage (Fig. 2(b), Table 1). Because this decrease occurred when no measurements were conducted between February 4 and 20, 2011, we looked to other sources to ascertain whether the flux decreased gradually or abruptly during this period and, if abruptly, when that change occurred. The video camera images show that 


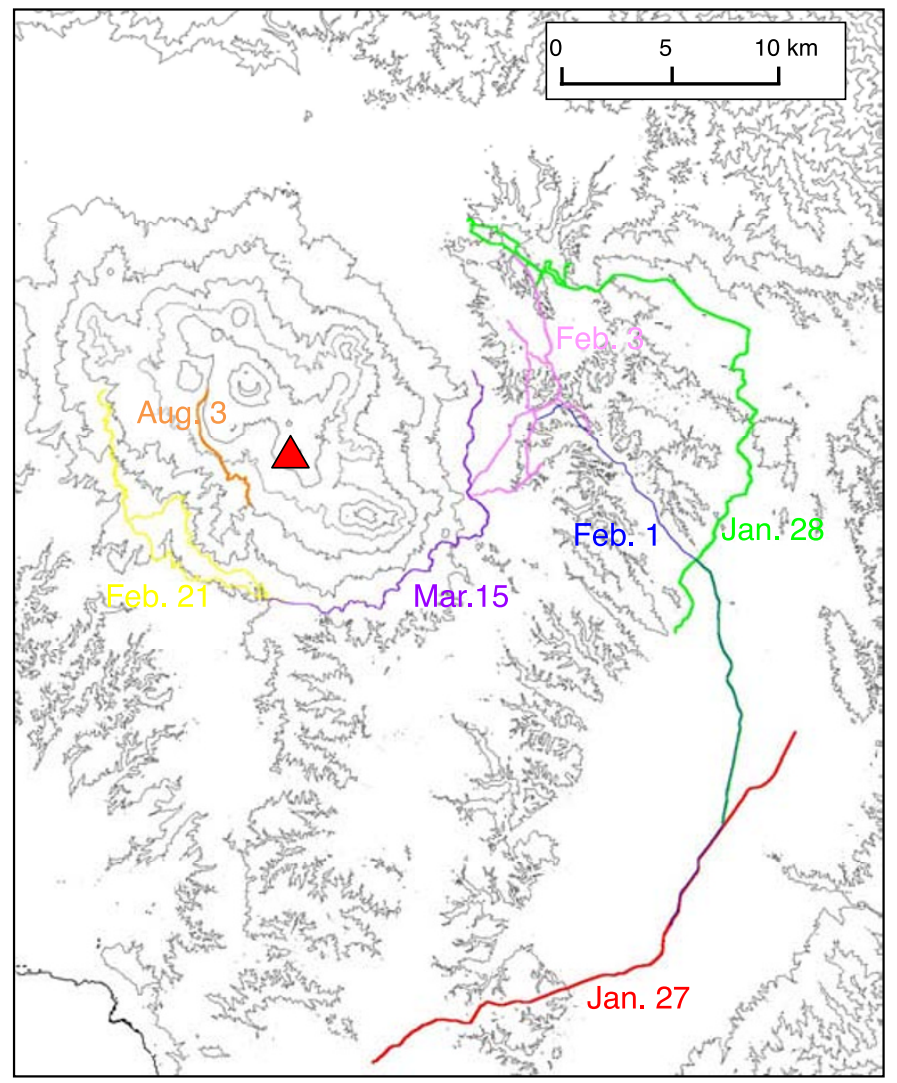

Fig. 1. Map showing the area around Kirishima volcano complex and seven typical traverse routes in 2011. Contours are drawn every $200 \mathrm{~m}$. The red triangle is Shinmoedake volcano. Observation dates are shown with the corresponding color beside the traverse routes.
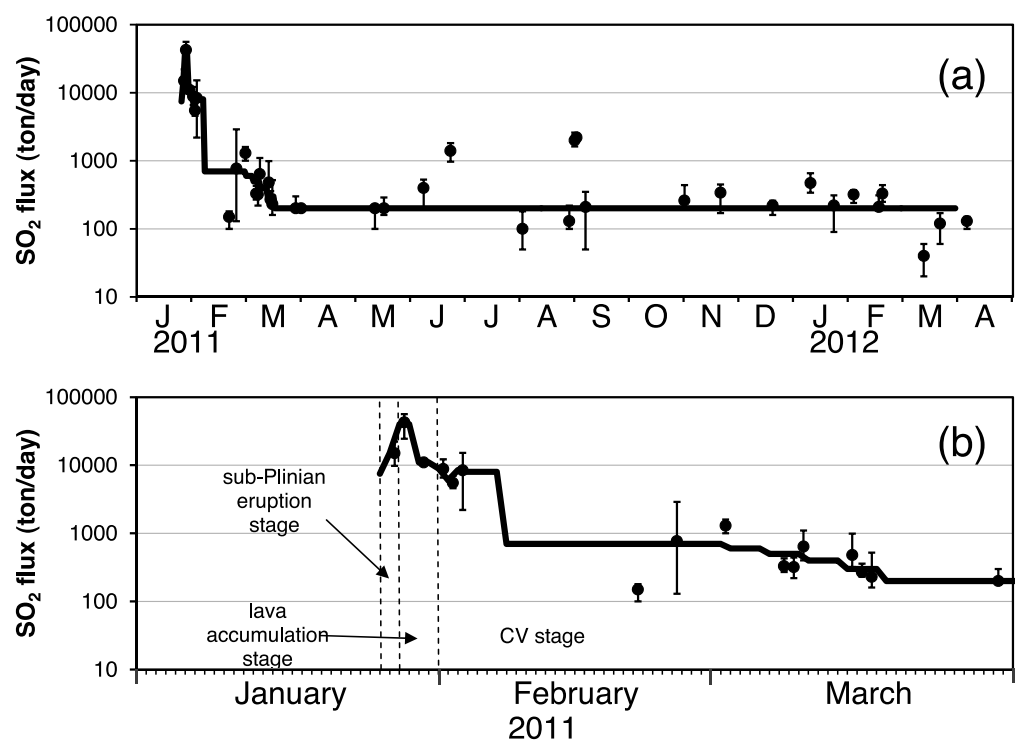

Fig. 2. Sulfur dioxide flux observed during the 2011 Shinmoedake volcano eruption. Solid circles show average $\mathrm{SO}_{2}$ flux of the observation day. Error bars show the range of the $\mathrm{SO}_{2}$ flux observed on the day. Solid lines show estimated daily $\mathrm{SO}_{2}$ flux calculated based on the observed $\mathrm{SO}_{2}$ flux (solid circles) and other information (see the text). (a) Sulfur dioxide flux between January 2011 and March 2012. (b) Sulfur dioxide flux during January-March 2011. The sub-Plinian eruption, lava accumulation and CV stages are shown with dashed lines.

the plume contained ash during the earlier period of the $\mathrm{CV}$ stage. The ash emission ceased and the visual size of the plume decreased considerably on the afternoon of February 7. Aerial photographs taken by helicopter observation also showed a lack of a strong plume from the central part of the lava between February 7 and 9 (JMA, 2012). Pho- tographs taken after Feb. 9 showed weak plume emissions from the periphery of the new lava and no plume emissions from the central part. Volcanic tremors that started on the morning of January 26 continued until 18:40 on February 7 and then occurred intermittently with decreasing frequency (JMA, 2012). During the early CV stage, the OMI images 
Table 2. Comparison of $\mathrm{SO}_{2}$ emissions with erupted magma mass and petrologically estimated $\mathrm{SO}_{2}$ emissions.

\begin{tabular}{|c|c|c|c|c|c|}
\hline Period & $\begin{array}{c}\text { Estimated } \\
\mathrm{SO}_{2} \\
\text { emission } \\
(\mathrm{kt})\end{array}$ & $\begin{array}{c}\text { Erupted } \\
\text { magma } \\
\text { mass } \\
(\mathrm{Mt})^{* 1}\end{array}$ & $\begin{array}{c}\text { Petrological } \\
\mathrm{SO}_{2} \\
\text { emission } \\
(\mathrm{kt})^{* 2}\end{array}$ & $\begin{array}{c}\text { Degree of } \\
\text { excess } \\
\text { degassing }\end{array}$ & Description \\
\hline Jan. 26-27, 2011 & 23 & $16-30^{* 3}$ & $16-30$ & $0.8-1.4$ & sub-Plinian eruption stage \\
\hline Jan. 28-31, 2011 & 102 & $35-45^{* 4}$ & $35-45$ & $2.3-2.9$ & lava accumulation stage \\
\hline Feb. 1-7, 2011 & 56 & — $^{* 6}$ & - & - & earlier CV stage \\
\hline Feb. 8-Mar. 31, 2011 & 26 & - & - & - & \\
\hline Jan. 26, 2011-Mar. 31, 2012 & 279 & $64-74^{* 5}$ & $64-74$ & $3.8-4.4$ & Total period \\
\hline \multicolumn{6}{|c|}{$\begin{array}{l}{ }^{* 1} \text { Erupted magma mass was calculated assuming the density of } 2.5 \mathrm{t} / \mathrm{m}^{3} \text { for reported eru } \\
{ }^{* 2} \text { Petrological } \mathrm{SO}_{2} \text { emissions were estimated using observed magma mass and the } \mathrm{S} \text { co } \\
2011 \text { ). } \\
{ }^{* 3} \text { Reference: Maeno } \text { et al. (submitted). } \\
{ }^{* 4} \text { References: Sasaki et al. }(2011) \text {, GIAJ (2012), NIED (2012). } \\
{ }^{*} \text { References: Furukawa } \text { et al. } \text { (2012), Sasaki et al. (2011), GIAJ (2012), NIED (2012). }\end{array}$} \\
\hline
\end{tabular}

(http://so2.gsfc.nasa.gov/) show $\mathrm{SO}_{2}$ plumes related to or probably related to Shinmoedake volcano until February 7 , after which the $\mathrm{SO}_{2}$ plumes related to the volcano were not identified in the images. These observations and evidence above support the inference that considerable changes in gas emissions occurred during February 7-9. Therefore, we inferred that the flux continued to be 8000 ton/day until February 7 , abruptly decreasing to 700 ton/day on February 8 , which is the average observed flux from February 21 to March 2, and continuing at 700 ton/day until the beginning of March (Fig. 2(b)). On February 13, $\mathrm{SO}_{2}$ measurements aimed at the summit area of Shinmoedake volcano were conducted from $7 \mathrm{~km}$ distance using COMPUSS. Sulfur dioxide was not detected in the measurements, which supports that the $\mathrm{SO}_{2}$ flux had decreased considerably by this day, even considering the underestimation of $\mathrm{SO}_{2}$ attributable to dilution effects (Mori et al., 2006b; Kern et $a l ., 2010)$. Based on the observed data (Table 1), we inferred that flux decreased gradually from 700 ton/day to 200 ton/day during March 1-20, 2011. This flux value continued for about a year until the end of March 2012 (Fig. 2(a)). Between March 20 and September 7, 2011, 11 small to extra small-scale eruptions occurred. After two of the eruptions (June 23 and August 31, 2011), data showing increased flux were obtained for a few days (June 24, September 1 and 2, 2011 in Table 1). In contrast, no significant increase was observed for two eruptions (March 23 and Sept. 7, 2011). For the remainder of the eruptions, no related flux data are available. Considering the points described above, we infer that an increase of flux over 1000 ton/day occurred for a few days for some of the eruptions. However these increases were omitted from our estimations presented in Fig. 2 because they were only short-lived and can not be evaluated adequately.

\section{Discussion}

Total $\mathrm{SO}_{2}$ emissions during January 26, 2011-March 31, 2012 were estimated as about $280 \mathrm{kt}$ based on estimated daily $\mathrm{SO}_{2}$ flux in Fig. 2 (Table 2). The sub-Plinian eruption and lava accumulation stages, and the earlier CV stage (February 1-7, 2011) respectively emitted 8\%, 37\% and $20 \%$ of the total emissions, which indicates that nearly two- thirds of the total emissions were emitted in the first two weeks (Table 2). Saito et al. (2011) estimated bulk sulfur content of $0.05 \mathrm{wt} \%$ for Shinmoedake volcano's magma using chemical analyses of minerals and melt inclusions. Based on the sulfur content, petrological $\mathrm{SO}_{2}$ emission can be estimated using the observed erupted magma mass (Table 2). The estimated $\mathrm{SO}_{2}$ emissions during the sub-Plinian eruption and lava accumulation stages were, respectively, 0.8-1.4 and 2.3-2.9 times greater than the petrological $\mathrm{SO}_{2}$ emissions. These values correspond to the degree of excess degassing (Shinohara, 2008). According to compiled data presented in table 3 of Shinohara (2008), the range of the degree of excess degassing for the 2011 Shinmoedake eruptions is at the low end of values for subduction zone volcanoes, which are 1-30 and 1-20, respectively, for explosive and effusive andesitic eruptions. The low value for the sub-Plinian eruption stage can be attributed to underestimation of observed $\mathrm{SO}_{2}$ flux (see the last paragraph in Section 5).

Three proposed mechanisms exist for the source of excess degassing: pre-eruptive bubbles in erupted magma, degassing of a convecting magma column, and a permeable gas flow model (Shinohara, 2008). For Plinian eruptions, pre-eruptive gas bubbles in a magma chamber are the strongest candidate (Wallace, 2001; Scaillet et al., 2003). For effusive eruptions, all three mechanisms can cause excess degassing, but the likelihood of pre-eruptive bubbles is especially strong for those that immediately follow an explosive eruption (Shinohara, 2008). Regarding the 2011 Shinmoedake eruption, if one assumes that the contribution of pre-eruptive bubbles is the source of excess degassing for the lava accumulation stages, then the relative amount of pre-eruptive bubbles in the magma chamber was probably low compared to the eruptions of Mt. St. Helens (Bluth et al., 1993; Gerlach and McGee, 1994) and Redout (Gerlach et al., 1994) volcanoes, which had similar explosive eruptive sequences followed by effusive eruptions, with a high degree of excess degassing (greater than 8 ) for eruptions of both types (Shinohara, 2008).

The transition from explosive to effusive eruption during the eruptive activity is observed elsewhere. This transition is regarded as attributable to extensive gas loss from 
magma in the conduit (Eichelberger et al., 1986; Jaupart and Allègre, 1991). In the 2011 Shinmoedake eruption, a lava dome was first viewed at the crater bottom in the morning of January 28, 2011 after the sub-Plinian eruption stage (Nakada et al., 2013). According to satellite SAR imagery analyses, the lava effusion rate was low on January 28 and was high during January 29-31 (NIED, 2012). In contrast, $\mathrm{SO}_{2}$ fluxes on January 28 and 29 were high compared to those on January 30 and 31 (Fig. 2(b)). The lack of positive correlation of gas emission and effusion rate, and the preceding high $\mathrm{SO}_{2}$ flux observed before the high effusion rate is apparently a result of the extensive degassing of magma in the conduit, which probably decreased the amount of gas in the magma and consequently played a role in the transition from explosive to effusive eruptions, as reported by Jaupart and Allègre (1991). Recent reports have described that shear deformation along the conduit wall of an uprising magma with bubbles might be an important mechanism for outgassing from magma by interconnection of bubbles or increasing permeability (e.g., Okumura et al., 2008, 2009; Namiki, 2012). Laboratory experiments by Namiki (2012) demonstrated the appearance of crack-like void spaces that can act as outgassing pathway in the deformation zone. Results of that study implied that efficient outgassing can occur at the beginning of the shear deformation. The outgassing pathway produced by shear deformation might be one candidate for the observed large flux at the beginning of lava effusion, but further study must be undertaken to elucidate the mechanism of flux change occurring from the end of the sub-Plinian eruption stage to the end of lava accumulation stage because the period must have been an important turning point for the eruptive activity of the 2011 Shinmoedake eruption.

Based on volcanic gas composition measured using a multicomponent gas analyzer system (MultiGAS; Aiuppa et al., 2005; Shinohara, 2005), $\mathrm{SO}_{2}$ flux data, and petrological information, Shinohara (2013) suggests that a convecting magma column model best explains the degassing mechanism for Shinmoedake, probably occurring after the end of the lava accumulation stage. During the CV stage, an abrupt decrease of the flux of about an order of magnitude occurred in about one day (Fig. 2(b)). To account for the decrease with the convecting magma column degassing model, abrupt decrease of conduit radius, increase of degassing depth, and change of magma properties should be considered. Because gas composition data support a shallow degassing depth of less than $500 \mathrm{~m}$, at least after March 2011 (Shinohara, 2013), the increase of the degassing depth is not relevant. Such a sudden decrease of conduit radius might be possible by collapse of the conduit wall, but no geophysical evidence exists to support that inference. We presume that depletion of pre-erupted bubbles in the magma chamber is the key, at least for the large decrease of the flux. The density difference between a non-degassed magma and a degassed magma is greater, as well as the amount of gas lost per volume of magma during the convection is also greater for magma containing bubbles compared to those of magma without pre-eruptive bubbles. Because the density difference is the major driving force for the convecting magma column degassing model (Kazahaya et al., 1994;
Shinohara, 2008), the depletion of pre-eruptive bubbles in uprising magma can markedly slow the convection speed and accordingly decrease the gas flux.

Closure of the outgassing pathway used in the previous stage is also a candidate for the decrease in the CV stage. Although lava effusion stopped seven days before the decrease (NIED, 2012), the established pathway could have been maintained until the outgassing pressure becomes below certain level. The pressure decrease probably corresponds to depletion of bubbles in the shear deformation zone. Both models described above can explain the large decrease of $\mathrm{SO}_{2}$ flux, but no strong evidence exists to show whether the decrease can occur abruptly in the order of a day.

Intrinsic limitations of the observation method affect the accuracy of $\mathrm{SO}_{2}$ emission estimates from the 2011 Shinmoedake eruption. One limitation is related to the spectral analyses method for quantification of $\mathrm{SO}_{2}$ and the other is related to time resolution of the traverse method. Kern et al. (2012) recently reported underestimation of the $\mathrm{SO}_{2}$ amount in traverse method using the conventional DOAS analysis when measuring $\mathrm{SO}_{2}$ in high aerosol optical density plumes. The traverse measurements on January 27 are probably influenced by this underestimation because of high ash density in the plume, however quantitative evaluation of the effect is still difficult and should be considered in future studies. The $\mathrm{SO}_{2}$ flux data used for this study was observed using traverse method not every day but sparsely and intermittently. Regarding flux calculations, results of 2-22 traverses conducted during just several hours around noon were averaged and reported as the flux representing the observation day. Therefore, substantial changes in flux or impulsive increases related to eruptions occurring before or after the observation period are not considered. Similarly, the estimated daily flux values (solid line in Fig. 2) are estimated based on interpolation of the observed flux data and based on supporting evidence. The $\mathrm{SO}_{2}$ emissions related to eruptions occurring during non-observational periods can not be evaluated accurately. Especially for the subPlinian eruption stage, our measurements do not include the peak sub-Plinian eruptions occurring during nighttime on January 26 and 27 (Nakada et al., 2013). Consequently, our estimated $\mathrm{SO}_{2}$ emissions for the sub-Plinian eruption stage (Table 2) are probably underestimated considerably. This underestimation explain the lower degree of excess degassing of the sub-Plinian eruption stage (Table 2) compared to those reported for andesitic explosive eruptions of arc volcanoes (Shinohara, 2008). The same kind of underestimation, but on a smaller scale, also exists for eruptions in other stages, especially after the second half of March 2011, during which we estimated the $\mathrm{SO}_{2}$ flux to be stable at 200 ton/day. These uncertainties are completely unavoidable unless truly continuous measurements of $\mathrm{SO}_{2}$ flux can be obtained. Although the use of automated $\mathrm{SO}_{2}$ flux monitoring techniques (e.g., Edmonds et al., 2003; Galle et al., 2010) might resolve some problems related to sparseness of the flux data, we would be unable to ascertain flux changes during the nighttime or during bad weather. Some innovative next-generation technique must be applied to solve the problem completely. 


\section{Conclusions}

Sulfur dioxide flux of the 2011 Shinmoedake eruption was repeatedly measured using COMPUSS from January 27,2011 , the day after the onset of the magmatic eruption. The flux was more than 10,000 ton/day during the subPlinian and lava accumulation stages. An abrupt decrease of about an order of magnitude was estimated to have occurred around February 8, 2011. The flux decreased gradually to about 200 ton/day by the second half of March 2011. This flux level continued for about a year until April 2012.

To calculate $\mathrm{SO}_{2}$ emissions of the 2011 eruption, we estimated the daily $\mathrm{SO}_{2}$ flux based on our observed $\mathrm{SO}_{2}$ flux data, images from video cameras, and plume height information and OMI images (http://so2.gsfc.nasa.gov/). The calculated total $\mathrm{SO}_{2}$ emission of the 2011 eruption was about 280 kt. During the 2011 eruption, nearly two-thirds of the total gas emissions were emitted during the first two weeks. The degree of excess degassing estimated for the sub-Plinian eruption and lava accumulation stages were, respectively, 0.8-1.4 and 2.3-2.9. These values are small compared to the values of previously reported eruptions, which had a similar eruptive sequence from explosive to effusive eruptions. Moreover, these values suggest a smaller pre-eruptive bubble content in the magma, at least for the lava accumulation stage. Sulfur dioxide flux during the lava accumulation stage was very high initially and was not subsequently correlated with the lava effusion rate. The high flux probably played a role in the transition from explosive to effusive eruptions. Another important feature in the degassing activity was an abrupt flux decrease of about an order of magnitude around February 8, 2011, which might be related to the depletion of pre-eruptive bubbles in the magma chamber.

Acknowledgments. We would like to thank members of Kagoshima Local Meteorological Observatory and Fukuoka District Meteorological Observatory, Japan Meteorological Agency for their support and information. We are also grateful to T. Ohba and an anonymous reviewer, and to T. Wright for their advice related to revisions. T. M. thanks A. Namiki for discussion. This research was supported by MEXT KAKENHI Grant No. 22900001 (S. Nakada) and by MEXT's Observation and Research Program for Prediction of Earthquakes and Volcanic Eruptions.

\section{References}

Aiuppa, A., C. Federico, G. Giudice, and S. Gurrieri, Chemical mapping of a fumarolic field: La Fossa Crater, Vulcano Island (Aeolian Islands, Italy), Geophys. Res. Lett., 32, L13309, 2005.

Bani, P., C. Oppenheimer, P. Allard, H. Shinohara, V. Tsanev, S. Carn, M. Lardy, and E. Garaebiti, First estimate of volcanic $\mathrm{SO}_{2}$ budget for Vanuatu island arc, J. Volcanol. Geotherm. Res., 212, 36-46, 2012.

Bluth, G. J. S., C. C. Schnetzler, A. J. Krueger, and L. S. Walter, The contribution of explosive volcanism to global atmospheric sulphur dioxide concentrations, Nature, 366, 327-329, 1993.

Daag, A. S., B. S. Tubianosa, C. G. Newhall, N. M. Tuñgol, D. Javier, M. T. Dolan, P. J. Delos Reyes, R. A. Arboleda, M. L. Martinez, and T. M. Regalado, Monitoring sulfur dioxide emission at Mount Pinatubo, in Fire and Mud: Eruptions and Lahars of Mount Pinatubo Philippines, edited by C. G. Newhall and R. S. Punongbayan, pp. 409-414, Philippine Institute of Volcanology and Seismology, Quezon City, and University of Washington Press, Seattle, 1996.

Edmonds, M., R. A. Herd, B. Galle, and C. M. Oppenheimer, Automated, high time-resolution measurements of $\mathrm{SO}_{2}$ flux at Soufriere Hills Volcano, Montserrat. Bull. Volcanol., 65, 578-586, 2003.

Eichelberger, J. C., C. R. Carrigan, H. R. Westrich, and R. H. Price, Nonexplosive silicic volcanism, Nature, 323, 598-602, 1986.
Furukwawa, R., N. Geshi, T. Oikawa, T. Chiba, S. Nakada, and M. Nagai, Pyroclastic fall deposit and eruptive mass of 2011 eruption from Shinmoedake volcano, Kirishima volcanic group, Japan Geosci. Union Meeting Abstract, SVC50-P36, 2012.

Galle, B., C. Oppenheimer, A. Geyer, A. McGonigle, M. Edmonds, and L. Horrocks, A miniaturised ultraviolet spectrometer for remote sensing of $\mathrm{SO}_{2}$ fluxes: A new tool for volcano surveillance, J. Volcanol. Geotherm. Res., 119, 241-254, 2002.

Galle, B., M. Johansson, C. Rivera, Y. Zhang, M. Kihlman, C. Kern, T. Lehmann, S. Arellano, and S. Hidalgo, Network for observation of volcanic and atmospheric change (NOVAC)—A global network for volcanic gas monitoring: Network layout and instrument description, $J$. Geophys. Res., 115, D05304, 2010.

Gerlach, T. M. and K. A. McGee, Total sulfur dioxide emissions and pre-eruption vapor-saturated magma at Mount St. Helens, 1980-88, Geophys. Res. Lett., 21, 2833-2836, 1994.

Gerlach, T. M., H. R. Westrich, T. J. Casadevall, and D. L. Finnegan, Vapor saturation and accumulation in magmas of the 1989-1990 eruption of Redoubt volcano, Alaska, J. Volcanol. Geotherm. Res., 62, 317-337, 1994.

Geshi, N., S. Takarada, M. Tsutsui, T. Mori, and T. Kobayashi, Products of the August 22, 2008 eruption of Shinmoedake volcano, Kirishima Volcanic Group, Japan, Bull. Volcanol. Soc. Jpn., 55, 53-64, 2010 (in Japanese with English abstract).

GIAJ (Geospatial Information Authority of Japan), Crustal deformations around Kirishima Volcano, Rep. Coord. Comm. Predict. Volcan. Erup., 108, 197-220, 2012 (in Japanese).

Horton, K. A., G. Williams-Jones, H. Garbell, T. Elias, A. J. Sutton, P. Mouginis-Mark, J. N. Porter, and S. Clegg, Real-time measurement of volcanic $\mathrm{SO}_{2}$ emissions: Validation of a new UV correlation spectrometer (FLYSPEC), Bull. Volcanol., 68, 323-327, 2006.

Jaupart, C. and C. J. Allègre, Gas content, eruption rate and instabilities of eruption regime in silicic volcanoes, Earth Planet. Sci. Lett., 102, 413-429, 1991.

JMA (Japan Meteorological Agency), National Catalogue of the Active Volcanoes in Japan (third edition). Japan Meteorological Agency, 635 pp., 2005 (in Japanese).

JMA (Japan Meteorological Agency), Volcanic activity of Kirishimayama Volcano-June-September 2010-, Rep. Coord. Comm. Predict. Volcan. Erup., 107, 154-166, 2011 (in Japanese).

JMA (Japan Meteorological Agency), Volcanic activity of Kirishimayama Volcano-February-May, 2011-, Rep. Coord. Comm. Predict. Volcan. Erup., 109, 139-167, 2012 (in Japanese).

Kamada, M., K. Ota, and N. Matsuwo, $\mathrm{SO}_{2}$ (sulfur dioxide) emission from Minamidake, Sakurajima volcano, 1975-1982, Report of the Fifth Joint Observation of Sakurajima Volcano (Oct.-Dec., 1982), 89-95, 1986.

Kazahaya, K., H. Shinohara, and G. Saito, Excessive degassing of IzuOshima volcano: Magma convection in a conduit, Bull. Volcanol., 56, 207-216, 1994.

Kern, C., T. Deutschmann, L. Vogel, M. Wöhrbach, T. Wagner, and U. Platt, Radiative transfer corrections for accurate spectroscopic measurements of volcanic gas emissions, Bull. Volcanol., 72, 233-247, 2010.

Kern, C., T. Deutschmann, C. Werner, A. J. Sutton, T. Elias, and P. J. Kelly, Improving the accuracy of $\mathrm{SO}_{2}$ column densities and emission rates obtained from upward-looking UV-spectroscopic measurements of volcanic plumes by taking realistic radiative transfer into account, J. Geophys. Res., 117, D20302, 2012.

Kinoshita, K., N. Iino, C. Kanagaki, I. Harada, J. Park, and M. Sakamoto, Ground observation and satellite image analysis of eruption clouds at Kirishima-Shinmoedake volcano, Japan Geosci. Union Meeting Abstract, SVC070-P16, 2011.

Krotkov, N. A., S. A. Carn, A. J. Krueger, P. K. Bhartia, and K. Yang, Band residual difference algorithm for retrieval of $\mathrm{SO}_{2}$ from the aura ozone monitoring instrument (OMI), IEEE Transactions on Geoscience and Remote Sensing, 44, 1259-1266, 2006.

Maeno, F., M. Nagai, S. Nakada, R. Burden, S. Engwell, Y. Suzuki, and T. Kaneko, Constraints on tephra dispersal from andesitic subplinian explosions of the Shinmoedake volcano, Kirishima, Japan, on 26-27 January 2011, Bull. Volcanol., (submitted).

McGonigle, A. J. S., C. Oppenheimer, V. I. Tsanev, S. Saunders, K. Mulina, S. Tohui, J. Bosco, J. Nahou, J. Kuduon, and F. Taranu, Sulphur dioxide fluxes from Papua New Guinea's volcanoes, Geophys. Res. Lett., 31, L08606, 2004.

Mori, T., K. Kazahaya, C. Oppenheimer, A. J. S. McGonigle, V. Tsanev, R. Olmos, M. Ohwada, and T. Shuto, Sulfur dioxide fluxes from the volcanoes of Hokkaido, Japan, J. Volcanol. Geotherm. Res., 158, 235- 
243, $2006 \mathrm{a}$.

Mori, T., T. Mori, K. Kazahaya, M. Ohwada, J. Hirabayashi, and S. Yoshikawa, Effect of UV scattering on $\mathrm{SO}_{2}$ emission rate measurements, Geophys. Res. Lett., 33, L17315, 2006 b.

Mori, T., J. Hirabayashi, K. Kazahaya, T. Mori, M. Ohwada, M. Miyashita, and H. Iino, A compact ultraviolet spectrometer system (COMPUSS) for monitoring volcanic $\mathrm{SO}_{2}$ emission: Validation and preliminary observation, Bull. Volcanol. Soc. Jpn., 52, 105-112, 2007.

Nakada, S., M. Nagai, T. Kaneko, Y. Suzuki, and F. Maeno, The outline of the 2011 eruption at Shinmoe-dake (Kirishima), Japan, Earth Planets Space, 65, this issue, 475-488, doi:10.5047/eps.2013.03.016, 2013.

Namiki, A., An empirical scaling of shear-induced outgassing during magma ascent: Intermittent magma ascent causes effective outgassing, Earth Planet. Sci. Lett., 353-354, 72-81, 2012.

NIED (National Research Institute for Earth Science and Disaster Prevention), Temporal change of Lava in the Shinmoe-dake crater detected by SAR images, Rep. Coord. Comm. Predict. Volcan. Erup., 108, 234-235, 2012 (in Japanese).

Okumura, S., M. Nakamura, A. Tsuchiyama, T. Nakano, and K. Uesugi, Evolution of bubble microstructure in sheared rhyolite: Formation of a channel-like bubble network, J. Geophys. Res., 113, B07208, 2008.

Okumura, S., M. Nakamura, S. Takeuchi, A. Tsuchiyama, T. Nakano, and K. Uesugi, Magma deformation may induce non-explosive volcanism via degassing through bubble networks, Earth Planet. Sci. Lett., 281, 267-274, 2009.

Oppenheimer, C., A. J. S. McGonigle, P. Allard, M. J. Wooster, and V. Tsanev, Sulfur, heat, and magma budget of Erta'Ale lava lake, Ethiopia, Geology, 32, 509-512, 2004.

Platt, U. and J. Stutz, Differential Optical Absorption Spectroscopy: Principles and Applications, 272 pp., Springer-Verlag, Heidelberg, 2008.

Saito, G., N. Geshi, and H. Shinohara, Magma mixing and degassing processes of Kirishima 2011 eruption based on chemical analyses of minerals and melt inclusions, Program Abstract Volcanol. Soc. Japan 2011 Fall Meeting, 30, 2011 (in Japanese).

Sasaki, H., K. Isobe, S. Homma, M. Sakagami, S. Mukoyama, S. Nakada,

T. Kobayashi, and M. Murakami, Estimation of lava volume using oblique aerial photo in Shinmoedake Volcano, Program Abstract Volcanol. Soc. Japan 2011 Fall Meeting, A1-13, 2011 (in Japanese).

Scaillet, B. J., F. Luhr, and M. R. Carrol, Petrological and volcanological constraints on volcanic sulfur emissions to the atmosphere, in Volcanism and the Earth's Atmosphere, edited by A. Robock and C. Oppenheimer, pp. 11-40, Geophys. Monogr. Ser., vol. 139, AGU, Washington, D.C., 2003.

Shinohara, H., A new technique to estimate volcanic gas composition: Plume measurements with a portable multi-sensor system, J. Volcanol. Geotherm. Res., 143, 319-333, 2005.

Shinohara, H., Excess degassing from volcanoes and its role on eruptive and intrusive activity, Rev. Geophys., 46, RG4005, 2008.

Shinohara, H., Composition of volcanic gases emitted during repeating Vulcanian eruption stage of Shinmoedake, Kirishima volcano, Japan, Earth Planets Space, 65, this issue, 667-675, doi:10.5047/eps.2012.11.001, 2013.

Stoiber, R. E., J. L. L. Malinconico, and S. N. Williams, Use of correlation spectrometer at volcanoes, in Forecasting Volcanic Events, edited by $\mathrm{H}$. Tazieff and J. C. Sabroux, pp. 425-444, ELSEVIER, New York, 1983.

Wallace, P. J., Volcanic $\mathrm{SO}_{2}$ emissions and the abundance and distribution of exsolved gas in magma bodies, J. Volcanol. Geotherm. Res., 108, 85106, 2001.

T. Mori (e-mail: mori@eqchem.s.u-tokyo.ac.jp) and K. Kato 